\title{
THE EFFECT OF ENVIRONMENTAL FLIGHT CONDITIONS ON DAMAGE PROPAGATION IN COMPOSITE SANDWICH STRUCTURE
}

\author{
Piotr Synaszko \\ Michał Salaciński \\ Lukasz Kornas \\ Air Force Institute of Technology, ul. Księcia Bolestawa 6, 01-494 Warsaw, Poland
}

\begin{abstract}
The aim of the study was to determine the traceability of damage growth caused by inclusions of water in the composite sandwich structure. It was assumed that as a result of temperature changes during the flight and accompanying phase transformation, the zone containing water inclusions increases. The growth is caused by the destruction (mainly the tearing of walls) of the core. As part of the work, this assumption was verified experimentally. For the experiment to be successful it was necessary to simulate actual flight conditions. The simulation involved inducing phase transformations of water in the core cell as a function of time and temperature. Before and after the experiments the non-destructive tests using pulsed thermography were performed. The test results revealed an increase in the number of cells occupied by water. Adequate specimens were designed and manufactured. The study showed that cyclical changes in temperature affected the propagation of water in core sandwich structures. Further, it was found that the increase in the surface area of water-containing inclusions could be monitored using thermographic techniques.
\end{abstract}

Keywords: honeycomb structures, detection of water ingress, thermografic techniques.

\section{INTRODUCTION}

An aircraft is operated in changeable weather conditions. In particular, temperature changes depending on altitude. During the cruise on flight level FL330 (10.000 [m]) temperature falls to $50 \mathrm{C}$ [1]. After landing, while standing on the apron on a hot day, the temperature of the airplane's surface could be higher by over $30^{\circ} \mathrm{C}$ than that of the environment [2]. Composite airframe can operate in these conditions. Situation changes however, if damage has occurred. Changes in environmental conditions may result in the acceleration of the destruction processes. This paper describes the influence of freeze - thaw cycles on a damaged composite honeycomb sandwich structure made of AFRP (skin) and 3mm diameter Nomex ${ }^{\circledR}$ honeycomb (core).

\section{PROBLEM DESCRIPTION}

Composite honeycomb sandwich structures are widely used in aircraft due to their light weight, stiffness, strength, fatigue resistance and low manufacturing cost, the example being C-295 used by the Polish Air Force. Some fuselage panels in C-295 have been made of honeycomb sandwich. The outer surface of the sandwich structure is exposed to surface damage due to collisions with small objects. These type of damage involving small cracks and delaminations creates conditions for the penetration of water inside the sandwich structure [3]. 
An aircraft is operated in changing weather conditions. During its climb to the cruising altitude, the temperature outside decreases from $30^{\circ} \mathrm{C}$ to $-50^{\circ} \mathrm{C}$ Then, after the flight on the cruising level the plane descends and lands, it usually stands on the apron where the temperature of the composite surface rises. During the aircraft flight, inside the sandwich panel, the freeze-thaw cycle takes place [4]. Cyclic water phase transitions lead to further damage development by destroying the bonding between the skin and the core in the honeycomb panel [5]. The authors modeled this phenomenon in order to check if it was possible to track increase damage.

\section{EXPERIMENTAL MODELING}

A series of aircraft flights (standing on the apron - flight - standing on the apron) was modelled as a series of changes in temperature. To simplify the experiment the changes in pressure and humidity occuring during flights were neglected.

Composite sandwich specimens with the skin made of aramid-epoxy composite and honeycomb core material Nomex ${ }^{\circledR}$ were designed and manufactured. They were made of prepreg using heating blankets (Fig. 1). In center of each Specimen there were made 4 holes having a diameter of $1 \mathrm{~mm}$ and spaced at a distance of about $10 \mathrm{~mm}$. Then, water was applied through the holes.
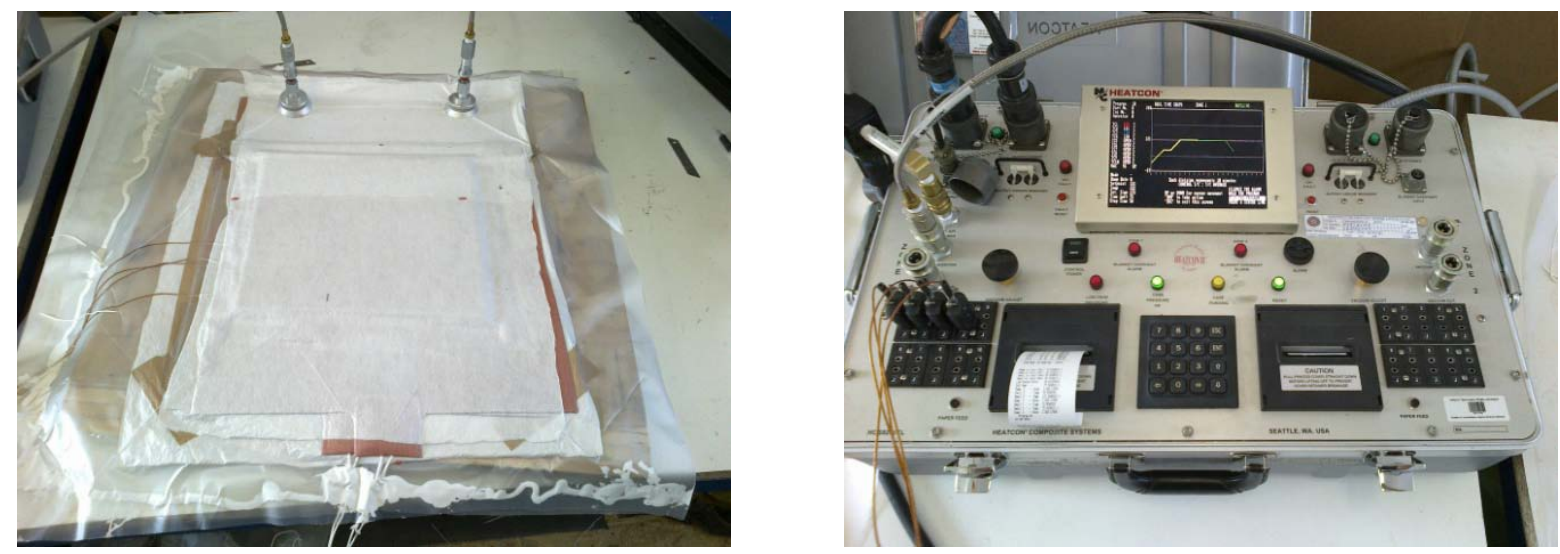

Figure 1. Honeycomb panel during curing cycle
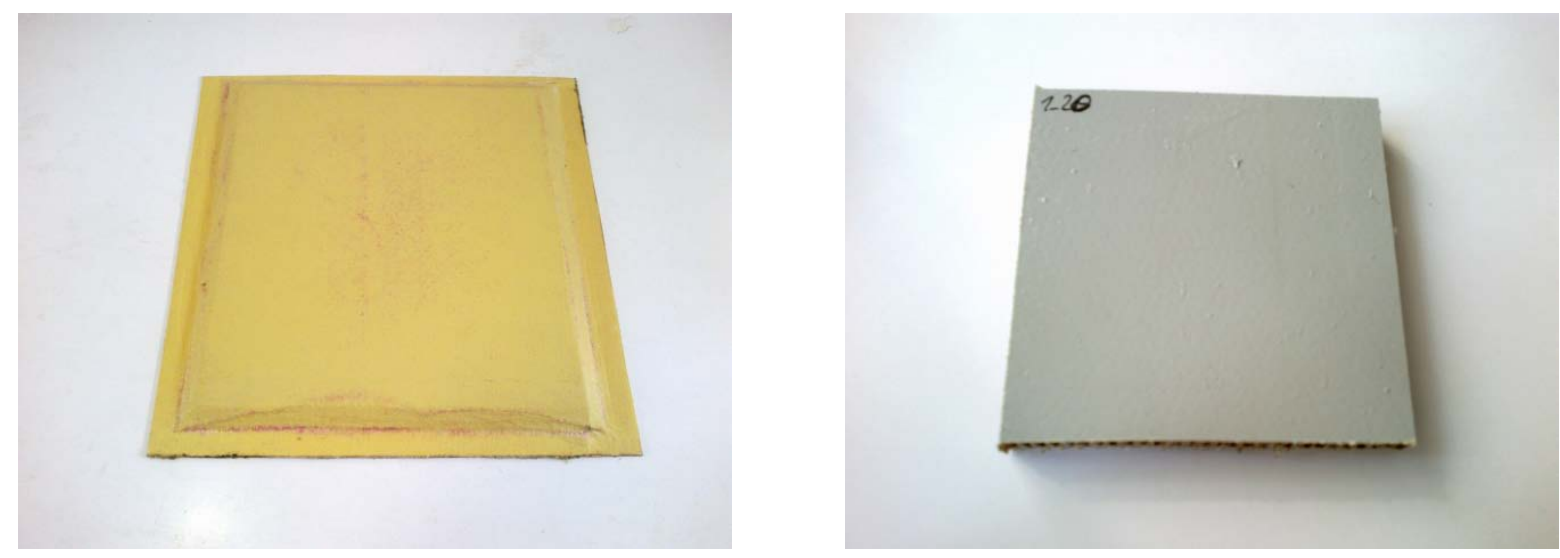

Figure 2. Honeycomb panel after curing (left), one of the specimens (right)

The simulation involved a 3-hour cycle simulating the aircraft's take-off and climb to the altitude of $6000[\mathrm{~m}]$ and then descent, landing and parking on the apron. The specimens were cooled to a temperature of $-25^{\circ} \mathrm{C}$ and then heated to room temperature in forced convection conditions. During the experiment, temperature was recorded. Thermocouple was located inside 
the core cell. The correlation between the altitudes and related temperatures was assumed based on the standard atmosphere [1].

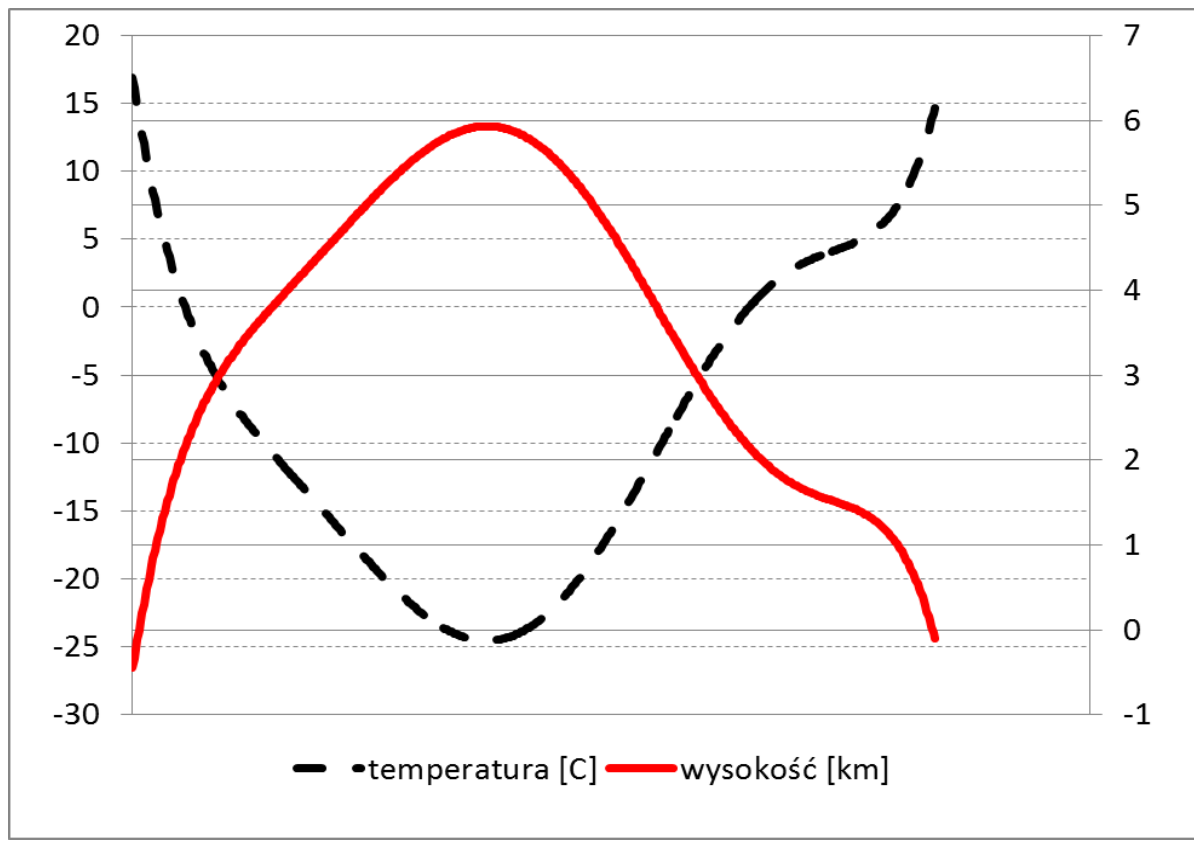

Figure 3. Temperature profile recorded during freeze-thaw cycles. Continuous line represents altitude calculated from standard atmosphere

\section{RESULTS}

Prior to the experiment reference measurements were recorded using a pulsed thermography system. The specimens were divided into two groups of three samples. The first group of samples was stored for the entire duration of the experiment in temperature between $15-25^{\circ} \mathrm{C}$ and humidity between $40-60 \%$. The second group was subjected to freeze-thaw cycles. After three cycles the specimens were inspected again and the results were compared with those obtained from the first inspection.

It was observed that the number of cells with water inclusions increased. The area of water inclusions expanded into the adjacent cells. The results of inspections are shown in Figure 4 and Figure 5.
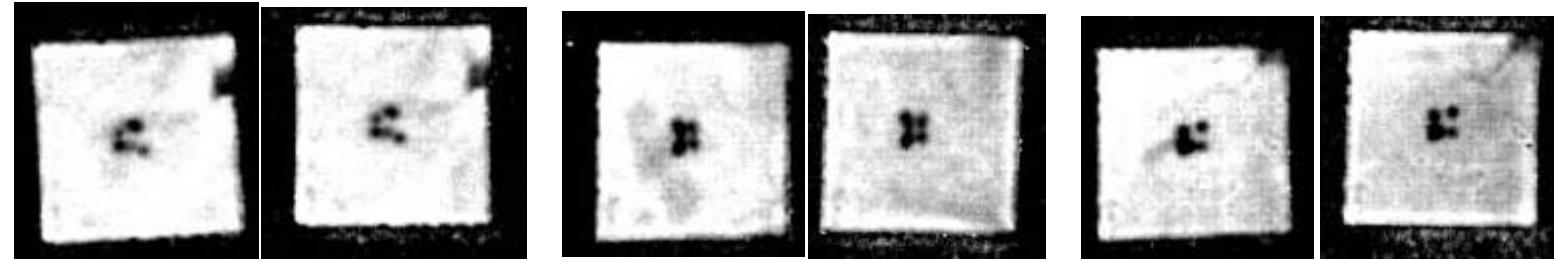

Figure 4. The results of the NDT of three specimens before and after the experiment. The specimens were not subjected to freezing cycles. Initial state on the left side. The final state on the right side
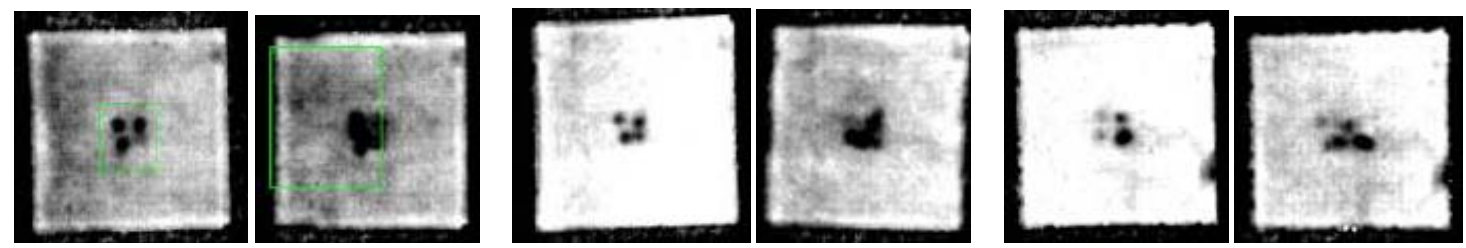

Figure 5. The results of the NDT of three specimens before and after the experiment. The specimens were subjected to freezing cycles. Initial state on the left side. The final state on the right side 


\section{SUMMARY}

The authors presented the problem related to the effect of weather conditions on a sandwich structure containing inclusions of water. It was proposed a simplified model of the physical phenomena feasible to perform under the laboratory conditions. The sandwich structure samples were designed and manufactured according with the technology used in aviation. The tests were performed at the Air Force Institute of Technology. Based on the results obtained it can be concluded that it is possible to track the increase in the size of the water inclusion.

\section{REFERENCES}

[1] Meteorologia dla pilotów- poradnik, Szefostwo Służby Meteorologicznej Sił Zbrojnych RP, Warszawa 2011.

[2] G. Wypych, Handbook of Environmental Degradation of Materials, ChemTec Publishing, 2003, ISBN 1-895198-28-3

[3] H. Gandy, „Adhesiveless Honeycomb Sandwich Structure With Carbon Graphite Prepreg For Primary Structural Application: A Comparative Study To The Use Of Adhesive Film” Thesis by H. Gandy, Wichita State University, 1999.

[4] Choi H.S. ,Jang Y.H., Bondline strength evaluation of cocure/precured honeycomb sandwich structures under aircraft hygro and repair environments, Composites: Part A 41 (2010)

[5] Ibarra-Castanedo C., Marcotte F., Genest M., Brault L., Farley V., Maldague X. P. V., Detection and characterization of water ingress in honeycomb structures by passive and active infrared thermography using a high resolution camera, $11^{\text {th }}$ International Conference on Quantitative InfraRed Thermography 2012

[6] Bartholomeusz R.A., Reduction of shear and flatwise tension strength in f-111 honeycomb panels exposed to moisture, DSTO-TR-1331, 1996 